\title{
Seven Types of Animality, Or: Lessons from Reading and Teaching Animal Fictions
}

\author{
Roman Bartosch \\ Universität zu Köln, Germany
}

Copyright (c) 2020 by Roman Bartosch. This text may be archived and redistributed both in electronic form and in hard copy, provided that the author and journal are properly cited and no fee is charged for access.

\begin{abstract}
This essay delves into the diversity of animal stories in human meaning ecologies and argues that the 'lessons' to be derived from these stories revolve around the meaning and effect of various forms of ambiguity. Following the route of a selection of mostly Irish canonical texts, from Swift's Gulliver's Travels to Seamus Heaney's Death of a Naturalist, it formulates seven lessons for reading and teaching animal fictions in a multispecies world. It argues that we must cultivate a sense of 'ciferal' reading that does not resolve but thrives productively on the tensions and ambiguities of human-animal relations that literary fiction excels in putting into words.
\end{abstract}

Key Words. Human-animal Studies, Jonathan Swift, W.B. Yeats, Seamus Heaney, Rainer Maria Rilke, Ambiguity, Posthumanism, Zoopoetics.

Resumen. Este ensayo profundiza en la diversidad de historias de animales en las ecologías humanas y sostiene que las "lecciones" que se derivan de estas historias giran en torno al significado y el efecto de diversas formas de ambigüedad. Basándose en una selección de textos canónicos principalmente irlandeses, desde Gulliver's Travels de Jonathan Swift hasta Death of a Naturalist de Seamus Heaney, el ensayo formula siete lecciones para leer y enseñar ficciones de animales en un mundo multiespecie. Sostiene que debemos cultivar un sentido de lectura "cifrado" que no resuelve sino que se nutre fructíferamente de las tensiones y ambigüedades de las relaciones humano-animal en las que la ficción literaria sobresale al traducirlas en palabras.

Palabras clave. Estudios humano-animal, Jonathan Swift, W. B. Yeats, Seamus Heaney, Rainer Maria Rilke, ambigüedad, posthumanismo, zoopoética. 
Gulliver has seen it all. He has visited Lilliput and Brobdingnag, has conferred with the sages in Laputa and, eventually, Japan. But then he chances upon something - someone - who up to this day seems truly and outrageously surreal: the wise horses known as... well, more on the name later. The horses he meets on his last voyage are "endowed by nature with a general disposition to all virtues", and "their grand maxim is to cultivate reason" (Swift 306). Their Platonism writ large contrasts sharply with the "ugly monster[s]" known as the Yahoos who, as is well known, are disgusting, embarrassing in their vulgar corporeality and anthropomorphic obscenity. Encountering horses and men in this strange land changes Gulliver profoundly, and it seems clear that conversing with animals comes at a price. And yet, this is what we do, or strive to do, in literary animal studies. What, then, is the nature, and what are the conditions, of such literary transformations?

This article presents not a systematic account of human-animal stories and relations but an inventory of narrative events, topoi, and 'lessons' to be derived from these encounters with literary animality. In playing with the notion of 'lessons' in a way comparable to Kelly Oliver's (2009) philosophical mappings, my aim is in taking stock of the ways in which fiction influences, and refigures, what we think we know about animals (and humans). Hence the title, 'Seven Types of Animality': With an obvious nod to William Empson's work on literary ambiguity, the essay argues that reading and teaching animal fiction requires an openness towards ambiguous textual creatures and narrative meanings that can and ought to be cultivated in what I will describe as 'ciferal' reading practices. Ciferal readings, I will try to show, are not meant to celebrate some form of potentially subversive wildness but inhabit "the border's border" (Garrard, "Ferality" 256) as they engage with the symbolism of animal narratives while at the same time resisting the domesticating impulse of allegorical readings of animals, emphasising moments of shared semiotic agency instead.

\section{Conversing with Animals: Theoretical Perspectives}

If we follow the lead of Gulliver's encounter and the many human-animal stories that followed (and preceded) it - where do we find ourselves? Assuming that such narratives prove "useful for interrogating key elements of identity and society, inspiring as well as confronting the limitations of knowledge" (McHugh 211) we have to ask, what is the nature of those literary lessons? What, in other words, can literary animals teach us? This question is one of the key concerns of literary and cultural animal studies, and of the environmental humanities more generally. Writing about 'challenges for historians' in the field, Hilde Kean ("Challenges") discusses various takes on historiography and animal agency, underscoring the role of the imagination of scholars needed for the development of new ways of reading animal histories. Likewise, and with an eye on the (im)possibilities of retrieving phenomenal and sensory experience in written artefacts studied by scholars, Erica Fudge comments on the role of imaginative writing and literary techniques in particular, which she says shows that "language works in part because it is an acknowledgment of the failure of language" (18). Such a forte of the literary imagination and its ability to complicate matters considerably is seconded by the philosopher of science, Vinciane Despret, who writes about the subject status and epistemic protocols of animal research and holds that philosophers and scientists "have an enormous problem of rivalry when it comes to language" (124, see also Hearne). The language Despret, like Hearne, is referring to is of course tied to the logocentrism of rationalist thought and its inability to engage in meaningful conversation with unequal others. Literary writing, by contrast, seems more attuned to a form of 'thinking-feeling' (Massumi 2008) where talking animal others have their place just as well as Yahoos and posthumanist seafarers. What is more, literary reading seems particularly apt for conversations with a 
somewhat enigmatic textual Other that relies on the ongoing readerly "endeavour to find new ways of creating and relating" (Rigby, "Ecopoiesis" 440) in narrative.

David Herman suggests as much when he transfers research from the cognitive sciences to literary studies and argues that fiction can help readers to understand human and nonhuman others through literary renderings of theories of mind, for instance: "fictional accounts can serve as a workspace for reconsidering - for critiquing, or re-affirming, dismantling or reconstructing - narratives about human selves in a world where selfhood extends beyond the domain of the human" ("Narratology" 132, see also Herman, Storytelling). Yet, while this might seem an overdue undertaking from a perspective that acknowledges the ways in which the sciences are slowly accepting nonhuman subjectivity and consciousness as scientific facts (see, for instance, the "Cambridge Declaration on Consciousness", Low), it does not mean that literary reading is a form of cognitive science. Marco Caracciolo reminds us of this when he states that:

Literary (imaginary) accounts of animal Umwelten may build on existing scientific knowledge, and they may serve a heuristic function in advancing it. This points to the feedback loop between literary and scientific explorations of mind, which Herman himself has often productively highlighted. Yet bringing to light a feedback loop should not lead to collapsing distinctions between a literary project and a more scientifically oriented phenomenology. (486)

Much remains to be said about underlying assumptions about literature and scientific endeavours here, or the complicated entanglements between both, however conceived (see Beer). But undoubtedly, Caracciolo has a point when he refers to the "different standards" of literature and science and the working of literary plausibility in rendering animal consciousness and environments. Such literary phenomenologies are not reliable in the scientific sense (cf. 496) but offer fine-grained accounts of animal consciousnesses within "a human, cultural dynamic" (498).

As we will see later, current ecopoetic research qualifies this statement with regard to the role of animal agencies in rhetoric and poetics. However, if the analytical focus is less on realist, and, thus, scientifically valid and allegedly objective, depictions of animal minds but on entering "a network of cultural meanings" (499), this undertaking is by nature experiential rather than experimental and less rigorously reliable than animal research in the sciences. At the same time, it is far more productive and necessary for gauging spaces of possibility for human-animal conviviality in moments of literary "singularity" (Attridge). As Attridge and others have argued, literary singularity manifests in events - and they are instantaneous but also enabled across ecologies of meaning of various texts and readers. Creating and nourishing such ecologies is contained in my notion of 'cultivation'; ferality, however, underlies my idea that if we are looking for singular events, the following remarks on literary animal encounters should be taken as a sketchy inventory of the lessons I learned from reading and roaming the literary rather than a systematic taxonomy. They are meant to map a number of possibilities for human-animal literary and cultural research as well as to shed light on disciplinary efforts at strengthening the environmental humanities.

\section{Lesson One: Gulliver's Shame}

As mentioned in the introductory paragraphs, Gulliver famously returns from the land of the Houyhnhnms a profoundly changed being. His return to the world of fellow humans is marked by the most extravagant renunciation of human ways of living both ethically and with regard to bodily issues such as the "offensive" "smell of a Yahoo" (Swift 339). Thus, we not 
only have the satirical and hyperbolic impression of a unique and superior 'horse sense'; Gulliver's encounter is significantly linked with a rush of shame that began with his first chancing upon the Yahoos and that would not recede throughout the narrative of Book Four:

several animals in a field, and one or two of the same kind sitting in trees. Their shape was very singular and deformed .... Their heads and breasts were covered with a thick hair, some frizzled and others lank; they had beards like goats, and a long ridge of hair down their backs and the fore-parts of their legs and feet, but the rest of their bodies were bare, so that I might see their skins, which were of a brown buff colour. They had no tails, nor any hair at all on their buttocks, except about the anus ... (Swift 253-254)

As readers are very well aware, these abominable Yahoos are human beings, seen from the strange perspective of a human forced into nonhuman focalisation by entering the enlightenment utopia of Houyhnhnm land. Bereft of the comforts of human exceptionalism, homo 'sapiens' appears as an abominably shameful collection of bodies. Interestingly, a similarly life-changing - if less antihumanist - moment of shame instigates Jacques Derrida's book-length investigation of the relationship between animals and philosophy, The Animal That Therefore I Am (2008). In both instances, bodily shame draws its intensity from the "double movement" of "painful individuation" and "uncontrollable relationality" (37), Eva Kosofsky Sedgwick has argued. Thus engendering a truly "disruptive moment" (36), shame "is itself a form of communication. Blazons of shame ... are semaphores of trouble and are at the same time of a desire to reconstitute the interpersonal bridge" (36, see also Bartosch). In light of the above remarks concerning the potential - and also the limitations - of literary writing in investigating more-than-human phenomenologies, we might pay closer attention to the literary rendering of shame as a "a form of communication". Reading literature, in this sense, requires and cultivates bridging self and other even across species divides -readers regularly create links with characters and their plights or feelings in moments of "uncontrollable relationality"; at the same time, literary texts can recreate the feeling of loneliness and "painful individuation" because of the diegetic divide between readers and characters.

In what I think is both an extremely clever and an equally funny move, Swift manages to create such a transdiegetic moment of human(ist) shame by prolonging the focaliser's diegetic 'posthumanisation' into the extradiegetic world of contemporary readers, as if knowingly knitting the "network of cultural meanings", mentioned above. Just think about, and feel free to ask colleagues sharing an interest in or institutional obligation towards Gulliver's Travels, how to pronounce "Houyhnhnm". There can be no mistake or debate, really, because the book is unambiguous: "the neighing of a horse" is the phonological model (Swift 257). This simple and little gesture makes it almost impossible for readers to invoke these Platonic Horse Philosophers and their utopian abode without a tinge of blazons of shame: who, after all, will engage in erudite academic exchange through human attempts at neighing? The description of the Yahoos takes its shaming energy from bodily disgust; the name of the superior horses, however, remains impossible for humans then and now to use without tainting this allegedly unique human trait by our inability to neigh. As Herman Josef Real puts it: "Swift's satire is double-edged. In a first cut, he shows that Man does not measure up to his own standard; in a second, that this self-fashioned standard is not for Man" (77). The first lesson, then, is in the challenges of animal fiction for such self-fashioned standards: In that they frequently produce affective moments of shame that work as a posthumanist antidote to gestures of human exceptionalism, animal fictions teach us a certain humility in the face of the ineffable. "An animal looks at us, and we are naked before it. Thinking perhaps begins there" (Derrida 29). 


\section{Lesson Two: Yeats's Surprise and Wonder}

Such posthumanist experience of humility depends to some extent on the surprise that literary animals draw on and instigate. Surprise of encounter is frequently employed as a motif in animal narratives and, like the moment of shame in Swift's narrative, it even sneaks into the extradiegetic world. William Butler Yeats's poem "Leda and the Swan" (1923) endorses a language of surprise when it begins with the line, "A sudden blow: the great wings beating still" and continues with the "staggering girl" (Yeats 182) - and while the choice of words in this opening suggests as much suddenness as surprise, the poet himself speaks of a moment of surprise upon setting out to write the poem: written in 1923 and published one year later, the poem exists because Yeats had been asked to write something for a political journal and had thought of "Leda and the Swan for metaphor" (quoted in Jeffares 296). He recollects, however, that as he was writing, "bird and lady took such possession of the scene that all politics went out of it ... " (ibid.). Such moments of "uncontrollable relationality" and literary agency are hardly isolated cases. Consider the 1919 poem, "The Cat and the Moon". Here, too, we have surprise and wonder as

The cat went here and there

And the moon spun round like a top,

And the nearest kin of the moon,

The creeping cat, looked up. (Yeats 141)

What happens then is that the speaker is surprised by the likeness of cat and moon - both highly symbolic in themselves of course - and cannot but wonder about the meaning, forever deferred, of this strange likeness:

Does Minnaloushe know that his pupils

Will pass from change to change,

And that from round to crescent,

From crescent to round they range?

Minnaloushe creeps through the grass

Alone, important and wise,

And lifts to the changing moon

His changing eyes. (Yeats 142)

Yeats speaks of this text as "a little poem" about an unruly cat that however depends to some extend on an allegorical reading in which the cat ought to be seen as "the normal man and ... as the opposite he seeks perpetually" - and yet, he ascertains that "no abstract idea must be present" (quoted in Jeffares 1968, 211).

As we follow such surprising animal encounters and the 'diegetic leaps' (Bergthaller) literary animals are capable of bringing about, we come to the second lesson: If humananimal studies wants "to unpack the complex interplay between the literal and the figurative, and the ways in which these textual animal presences come to signify in ways that gesture beyond the human, toward a less narrowly anthropocentric conception of the world' (Driscoll, "Second Glance" 33, original emphasis), it must cultivate an openness towards animal others that allows for surprise and wonder in the face of the nonhuman. 


\section{Lesson Three: Seeing Ciferal Agency}

But what of the "complex interplay between the literal and the figurative" - how to get to this "beyond" that Driscoll and others point to? There is good reason to assume that literary animals can lead the way through what manifests in texts as 'ciferal agency'. This expression - like the notion of 'ciferal' reading itself - references the work of Tom Tyler who writes about philosophical and literary attempts at capturing animals and opts for describing 'ciferae': always already caged in language and logocentrism, these 'ciphers' nevertheless engender an agency of their own - ferality - that the written word cannot fully contain (22). Human-animal studies, he suggests, teaches us to 'unlearn' the easy equation of animal figures and allegorical or metaphorical meaning, and readers are constantly asked to engage in "deciphering deciphering" (ibid.) when they attempt to learn from these ciferae.

In this way, literary analyses of animal stories, Greg Garrard argues, can show how stories enact a form of "narrarive ethics", especially over and against highly complex moral aporia, depending on "the degree to which naturalistic or fantastical elements in the story resist or encourage allegorical reading" ("Zoophilia" 229). Thus, "the techniques of storytelling ... have ethical import that might be distinct from, or even opposed to, the explicit moral positions assumed or debated within the storyworld" (ibid.). Constantly flitting to and fro between allegory and literality, literary animals can never be apprehended by a single mode of reading, a single way of seeing, exactly. Moving from a focus on the representation of both animals and human-animal ethics in fiction to the aesthetic agency of literature, Karí Driscoll thus describes literary animal studies, rightly I think, as "a field which has in part defined itself in opposition to traditional modes of reading animals in literature and art as symbols and metaphors for something other than themselves" ("Second Glance" 30).

Rosi Braidotti has therefore called for a "neoliteral reading" of animals: "Animals are no longer the signifying system that props up humans' self-projections and moral aspirations.

... They have, rather, started to be approached literally, as entities framed by code systems of their own" (528). But have they? The somewhat awkward syntax that suggests that animals have actively started to be passively approached suggests a more complex situation, in which neoliteral readings sit alongside cultural critiques, in postcolonial studies and elsewhere, that are alert to the naturalising epistemes of ongoing symbolic othering (cf. Ajuha; Lundblad).

The ensuing tension is crucial - and mobilises moments of meaningful recognition. In her history of animal rights in Britain, Hilda Kean repeatedly points out the importance of visibility, of being able to really see, the ethical plight of animals (Kean, Animal Rights 27). The same can be said about reading: it is bound to the ability and willingness to perceive. Derrida's famous chancing upon his little cat is one such instance where looking at an animal other in surprise and shame and wonder leads to a reconsideration not only of the cat herself but of our way of discursively confining animals. Likewise, literary animal presence, or the becoming-visible of ciferae, is often realised in writing through moments that literalise mutual recognition or at least apprehension. The latter has for instance concerned the poet Rainer Maria Rilke when, in the preface to Mitsou, he asks,

You think they look at us? Has anyone ever truly known whether or not they deign to register for one instant on this sunken surface of their retina our trifling forms? As they stare at us they might merely be eliminating us magically from their gaze, eternally replete. ... Has Man ever been their coeval? I doubt it. And I can assure you that sometimes, in the twilight, the cat next door pounces across and through my body, either unaware of me or as a demonstration to some eerie spectator that I really don't exist. (Rilke, Mitsou n.p.) 
As suggested above, the reciprocal gaze seems to be one of the most productive literary topoi when it comes to encountering the ciferal nature of literary animals (See Bartosch; Woodward). It is in the apprehension and recognition of an animal other that thinking begins, as Derrida suggests:

I must immediately make it clear, the cat I am talking about is a real cat, truly, believe me, a little cat. It isn't the figure of a cat. It doesn't silently enter the bedroom as an allegory for all the cats on earth, the felines that traverse our myths and religions, literatures and fables.... An animal looks at me. What should I think of this sentence? (4, 6, original emphases)

What, indeed? In literary writing, the moment of reciprocal gazing seems to be able to make use of, but also call into question, the philosophical associations tied to the 'facing' of others, as found in the work of Emmanuel Lévinas (2004). This can happen in clever plays on the question whether animals in fact have a face (for instance in J.M. Coetzee's short narrative "The Old Woman and the Cats", de Bruyckere and Coetzee). Or it is employed as strong affective energy in stories about individual animals and their human companions brought to the limits of logocentric understanding, as in Rilke's musing on fear and (animal) death in The Notebooks of Malte Laurids Brigge, published in 1910:

But I had been afraid even earlier. For example when my dog died. The same day that made me feel blameworthy once and for all. He was very ill. I had been kneeling all day beside him when suddenly he gave a short jerky bark as he used to do whenever a stranger came into the room. It was the type of bark that was reserved for such occasions, so to speak, and I automatically glanced towards the door. But [it] was already inside him. Worriedly I searched his eyes and he searched mine; but not to say our goodbye. He looked hard at me; he was displeased. He was accusing me of having let it in. He was convinced I could have prevented it. It was evident that he had always overestimated me. And there was no time left for me to explain. Disconsolate and lonely he kept his eyes fixed on me right to the end. (Rilke, Brigge n.p.)

In all of these instances, the gaze instigates mutual or painfully unanswered recognition and shared creaturely communication that at the same time also acknowledges radical alterity and the impossibility of unmediated communication across species, but also subject, lines (Rohman). "Lessons in animality" are lessons in ambiguity, after all: part of, yet partly removed from, the webs of meaning human beings are constantly spinning, literary animals invite us to dwell in this uncertainty and retain a sense of mystery when really looking closely into a realm where the absence of "the name and of the word" is "something other than a privation" (Derrida 48).

\section{Lesson Four: Heaney's Uncanny Realisations}

Dwelling in such uncertainty is, I want to argue, not only characteristic of thinking about (literary) animals but also deeply engrained in the aesthetic discourse of reading, which makes literature a surprisingly helpful and effective means of grasping some of the elusive truths about animality. These truths are not only conveyed in moments of encounter and recognition but may be distributed across larger scales of genre and textual archives. One of the strategies that extends beyond the single text as an intertextual web of literary atmosphere is the uncanny mood that often accompanies animal stories. Sigmund Freud's famous discussion of the uncanny draws explicitly on the psychologist Ernst Jentsch, who speaks of 
the uncanny "doubts whether an apparently animate being is really alive; or conversely, whether a lifeless object might not be in fact animate" (Freud 4). Looking at psychological research in the wake of the 1919 essay, one finds surprisingly numerous mentions of robots, puppets, or stuffed animals - but little mention of the fact that for many people, recent findings in animal ethology and psychology reveal animal others to be at least as uncanny as their fantastical counterparts: The thought that animals on a wide spectrum should not only be animate but "really alive", fully conscious and agential, isn't big news to human-animal scholars, of course. And yet, especially the recent trend of environmental horror, but also the countless instances of animal 'horror' in literature since Victorian times underlines that for many, animals are indeed "manifestation[s] of the uncanny" (Clark, Environment 185; see also Denenholz Morse and Danahay). It should then not come as a surprise when we understand how literature can be used to engender stronger senses of the 'strangely familiar', as in Seamus Heaney's "Death of a Naturalist":

... one hot day when fields were rank

With cowdung in the grass the angry frogs

Invaded the flax-dam; I ducked through hedges

To a coarse croaking that I had not heard

Before. The air was thick with a bass chorus.

Right down the dam gross bellied frogs were cocked

On sods; their loose necks pulsed like sails. Some hopped:

The slap and plop were obscene threats. Some sat

Poised like mud grenades, their blunt heads farting. (Heaney 5-6)

In this poem, Heaney makes some effort to describe this natural - almost pastoral - scene in ways that preempt the poetic persona's reaction of shock and the storyworld's horrifying promise:

I sickened, turned, and ran. The great slime kings

Were gathered there for vengeance and I knew

That if I dipped my hand the spawn would clutch it. (6)

That animality and animacy often go paw in hand and endorse atmospheres of the uncanny seems to point to a hunch in even the most ardent human exceptionalists that indeed, there is more aliveness in the world than they would usually acknowledge. This in turn supports the ethical claim by the likes of Tom Regan to conceive of animals as 'subjects of life'. Such literary fictions thus offer a way of seeing the world and its inhabitants as a complex web of shared agencies that have to be treated with care and humility while it also instigates fear and unease. The fourth lesson therefore revolves around the insight that animacy frequently leads to experiences of the uncanny. And it asks us to rethink the anxieties behind the recognition that animals are "really alive" in a phenomenologically rich and ethically relevant sense.

\section{Lesson Five: Heaney's Myths}

Given the far-reaching and existential dimensions of such profound animacies, there is little wonder that many animal narratives verge on the mythic, or at least employ language that resonates with mythic echoes in their shots at narrative anthropogenesis. Such is the case in Seamus Heaney's remarkable poem "A Dog Was Crying Tonight in Wicklow Also": "They sent the dog to Chukwu with a message" because 
They wanted to be let back to the house of life.

They didn't want to end up lost forever

Like burnt wood disappearing into smoke

Or ashes that get blown away to nothing. (Heaney 129)

The poem then describes how the dog gets distracted - or fails to accept the human message as worthy of further canine attention - and thus not only seals the fate of human mortality but also of human-dog relationships:

But death and human beings took second place

When he trotted off the path and started barking

At another dog in broad daylight just barking

Back at him from the far bank of a river. (129)

It is the dog's distraction that allows the toad to approach Chukwu and ascertain that "Human beings want death to last forever" and thus to solidify the distinction between pets and those abject animals that are connected with evil and mischief; and there is nothing left to do for the dog but to repent and remain at the humans' side:

... Great chiefs and great loves

In obliterated light, the toad in mud,

The dog crying out all night behind the corpse house. (130)

A similar conception of dog life can be found in Rainer Maria Rilke's poem "The Dog", notably very different from the much more famous "The Panther" whose poignant elegance made it one of the key texts in human animal studies (see Driscoll "Second Glance"). While the panther's "dance of strength around a centre" has become the epitome of empathy and tragedy for numerous readers, the dog is rather described in terrible and substantial dependence on his human master:

The image of a world takes shape up there, through glances he must constantly renew.

Some secret thing, though, comes at times, and where

he stands, stands next to him.

...

spending his reality, in doubt

almost, on things his gaze has not quite got -

$\cdots$

assenting to what he at last forgoes

because if he does not, he won't exist. (Rilke, “The Dog”)

Animal stories quite often go back to the very genesis of humans and human-animal relations or species divides. Myths and fairy-tales (see Sax 46), but also poems such as Ted Hughes's "Crow's First Lesson" (1970) or stories such as Jack London's Call of the Wild (1904), in engaging with deep time, the mythic, or the archaic, show that "animals are major templates used in the construction of human identity" (Sax 46) and the transhistoric relationship between humans and other animals. The fifth lesson tells us that we couldn't have become the species we are without the storying and meaning-making agency of earth others, rendering our humanly "fabricated world" (Rilke) a promisingly multispecies one. 


\section{Lesson Six: On Discipline}

My wanderings through the buzzing worlds of animal literature - sniffing here and there for guidance or meaning - is not meant to suggest, as said earlier, that we can deduce any taxonomy or systematic notion concerning the function(s) of animal narratives. This is partly because of the individual and subjective nature not only of interpretation but, more importantly, of the diegetic animals we encounter: "Most of the time, literature does not revolve around 'the' animal as an abstract category but presents us with a variety of diegetic and or semiotic-metaphoric species and animal individuals" (Middelhoff and Schönbeck 11). This, however, should not distract us from attempting to come to terms, as Middelhoff and Schönbeck suggest, with the role and potential of literature when it comes to reading earth others. It is, on the contrary, through what could I have described as 'ciferal' readings that we get a sense of the more-than-human aspects of what Susan McHugh calls 'narrative ethology'.

McHugh convincingly claims that "creative engagements with narrative forms" can help "[g]etting out from under the master narratives of evolution, ecology, and more pervasively of disciplines" because "stories can (and indeed always) do more than represent selves at the expense of others" (217). This is not to suggest that the sciences have no bearing on meaningful human-animal relations. But it underlines the importance - indeed, the occasional precedence of - narrative fictions when it comes to thinking animalities in the sciences as well as in everyday life (cf. McHugh 216). This particular form of literary agency emerges, as McHugh has shown, mostly through the "complicated operations of affect" (218). Thus, the peculiarities of literary form, intertextual kinship relations, and readerly inference might constitute the most important lesson this essay can hope to come to terms with. Such a lesson teaches us in which ways literature can "clear the field for cultivating a politics based not on the rights of homogeneous, atomized individuals so much as the affects that have always held together the heterogeneous, molecular groupings made so apparent in crossspecies companionship" (219).

Looking at the ways in which heterogeneous multispecies groupings "have always" been held together through fiction also allows for a novel way of looking at aesthetics. Karí Driscoll is one of those to endeavour such a project under the moniker of 'zoopoetics' and urges us not to overlook the ways "in which animals ... gesture always beyond the text in a way that renders their absence maximally significant" (Driscoll, "Absence" 164). With a nod to Derrida but, more importantly, to the alleged ignorance towards animality in works in the wake of the linguistic turn, he concludes: "Animality ... is the ultimate hors-texte" (166). Following Derrida's contention that animal figures and figurations of animality ought to be seen as "something that ... merits concern and attention ..., endlessly and from a novel perspective" (Derrida 6), zoopoetics "recognizes that nonhuman animals ... are makers ..., and they have agency in that making,", of fiction (Moe 2). It is therefore "not only concerned with the constitutions of the animal in and through language, but also the constitution of language in relation and opposition to the figure of the animal" (Driscoll, "Temptation" 223).

In its grappling with narratives of animality, fiction as a "negative ecopoetics" helps us explore both the limits and the potentials of language in encountering earth others (Rigby "Ecopoiesis"). Approaching ciferae teaches us that literary renderings of animals "must end in failure, but it is a productive failure, in that it ceaselessly pursues the outer limit of the representable and expressible" (Driscoll, "Absence" 166). Kate Rigby, who has worked on the implications of such negative poetics for the environmental humanities has recently suggested 'creaturely ecopoetics' as a term for such more-than-human semiosis that "[pushes] back against the hyper-separation of humans from other animals" by "disclosing continuities and connections among humans and other animals ... in multispecies matrices ... cobecoming" ("Creaturely" 281-282). 
As most of us are also teachers of literature, taking the notion of such matrices as cue for how to understand the pedagogic potential of literature when it comes to teaching crossspecies companionship and the role of literature is the last lesson I want to co-learn in this regard. We need, I take from the above, readings that take full advantage of the ambiguity of aesthetic animality through ciferal readings that are at the same time neoliteral and alert to symbolic networks. As Bart Welling and Scottie Kapel note, and this is the sixth lesson's key, the task lies in "presenting animals in the sense of making them present in literal, literary, bioregional and scientific terms, and ... equipping students with analytical tools with which to make sense of the contemporary flood of visual imagery, essentially re-presenting these representations" (Welling and Kapel 195). Animal fictions thus challenge our protocols of interpretation just as well as the disciplines that used to contain and domesticate narratives of the more-than-human. Teachers of animal fictions are thus called to interrogate how our complex ecologies of understanding the more-than-human interrelate, contradict, and bring forth multispecies conviviality through ambivalence and literary agencies. To keep text and readers alive in the contradictions and complexities such ecologies entail is what feral readings can muster.

\section{Lesson Seven: On Reading and Teaching Animals}

I want to conclude these musings by spelling out more clearly not only the pedagogic implications mentioned above, but also by providing one specific route to taking care if aesthetic and animal ambiguities. Research on climate change fiction has recently begun to identify, and make productive use of, the different scales that literary fiction employs in bringing home the idea of ambiguity and un-representability (Clark, Ecocriticism). Literary fiction is therefore equipped, one could argue, to help experience ambiguity in ways beneficial to making sense of the Anthropocene. Here, I would like to argue that the same can be said about aesthetic and animal ambiguities and that this is what we, as teachers of literature, should learn to cultivate.

Interestingly, a similar point has been made in a somewhat different context - of animal ethics and with an eye on the multiple uncertainties of how to read animal subjectivity. Matthew Calarco uses Guattari's 'three ecologies' as a productive starting point and suggests that "those of us who are interested in the current established order of human-animal relationships might profitably adopt" Guattari's three-pronged perspective on ethology that includes:

... a social ethology that is aimed at a careful study and consideration of what constitutes social life among animals as well as between human beings and animals ... an environmental ethology that undertakes an analysis of human-animal relations within their environmental milieu ... [and] a mental ethology that investigates the various practices that form and reform the character and subjective constitution of an individual animal, whether human or more-than-human. (Calarco 45-46)

I think what Calarco calls the 'three ecologies' can point to ways of feral reading that allow for incommensurable ambiguities and gather their strength exactly through the bringing together of the apparently heterogeneous or contradictory.

Looking again at the examples I have cited above from the vantage of social, environmental, and mental ecologies, we encounter a novel form of biosemiodiversity that constitutes the ultimate lesson of reading and teaching animal fictions. Gulliver's Travels are of course situated in the literary histories of Anglophone literatures, the tradition of satire, and the cultural conflicts between England and Ireland at the time of its writing, and between 
human and animal exploitation (social ecology). But it also makes use of actual humananimal relations and ecological knowledge that allows us to read the function of language but also the practices of neutering, keeping livestock, and social practices of mourning as environmental ecology. This, however, does not invalidate the very subjective, affective, and corporeal moments of shame I have described, particularly when it comes to the naming of the ineffable (mental ecology). Yeats and Heaney too are clearly situated in a historical situation that literary interpretation should take care of. But reading environmentally requires more, and sometimes incommensurable, readings of ecological proportions and individual affect. And the event of the literary gaze includes a social ecology of facing, face-saving and face-threatening just as much as an evolutionary and environmental dimension of kinship and its recognition. Maybe most importantly, it means that individual readers are looked at by very individual figurations of human-animal relationships realised in the form of a literary animal. These ecologies are not the same and cannot therefore lead to any final analysis of what it means to encounter literary animals. But they are meaningfully related, and it is in this sense of mind-boggling diversity that literature comes into its own. To cultivate a sense of these ecologies and their zoopoetic and affective interplay is what teachers of literature fighting for multispecies conviviality should take care of.

\section{Works Cited}

Ahuja, Neel. "Postcolonial Critique in a Multispecies World". PMLA 124. 2 (2009): 556-563. Attridge, Derek. The Singularity of Literature. London: Routledge, 2004.

Balthus and Rainer Maria Rilke. Mitsou. New York: The Metropolitan Museum of Art, 1984. Bartosch, Roman. "Reading Seeing: Literary Form, Affect, and the Creaturely Potential of Focalization". Beyond the Human-Animal Divide. Creaturely Lives in Literature and Culture. Ed. Dominik Ohrem and Roman Bartosch. Basingstoke: Palgrave Macmillan, 2017. 215-238.

Beer, Gillian. Open Fields. Science in Cultural Encounter. Oxford: Oxford University Press, 1999.

Bergthaller, Hannes. "Trees are what everyone needs': The Lorax, Anthropocentrism, and the Problem of Mimesis". Nature in Literary and Cultural Studies: Trans-Atlantic Conversations on Ecocriticism. Ed. Catrin Gersdorf and Sylvia Mayer. New York: Rodopi, 2006. 155-175.

Braidotti, Rosi. “Animals, Anomalies, and Inorganic Others". PMLA 124. 2 (2009): 526-532.

Calarco, Matthew. "The Three Ethologies" Exploring Animal Encounters. Philosophical, Cultural, and Historical Perspectives. Basingstoke: Palgrave Macmillan, 2018. 45-62.

Caracciolo, Marco. "'Three smells exist in the world': Literary Phenomenology in Italo Svevo's 'Argo and His Master'”. Modern Fiction Studies 60. 3 (2014): 484-505.

Clark, Timothy. The Cambridge Introduction to Literature and the Environment. Cambridge: Cambridge University Press, 2011.

Ecocriticism on the Edge. The Anthropocene as a Threshold Concept. London: Bloomsbury, 2015.

de Bruyckere, Berlinde and J.M. Coetzee. Cripplewood/Kreupelhout. New Haven and London: Yale University Press, 2013.

Denenholz Morse, Deborah and Martin A. Danahay, ed. Victorian Animal Dreams. Representations of Animals in Victorian Literature and Culture. Aldershot: Ashgate, 2007.

Derrida, Jacques. The Animal That Therefore I Am. Ed. Marie-Louise Mallet. Trans. David Wills. New York: Fordham University Press, 2008. 
Despret, Vinciane. "The Becomings of Subjectivity in Animal Worlds". Subjectivity 23 (2008): 123-129.

Driscoll, Kári. "The Sticky Temptation of Poetry". Journal of Literary Theory 9. 2 (2015): 212-229.

. "Second Glance at the Panther, or: What Does It Mean to Read Zoopoetically?" Frame 31. 1 (2018): 29-47.

"'Il n'y a pas de chats': Feline Absence and/as the Space of Zoopoetics". Texts, Animals, Environments. Zoopoetics and Ecopoetics. Ed. Friederike Middelhoff, Sebastian Schönbeck, Roland Borgards and Catrin Gersdorf. Freiburg: Rombach, 2019. 159-174.

Freud, Sigmund. "The Uncanny". July 2019. https://web.mit.edu/allanmc/www/freud1.pdf

Fudge, Erica. "Milking Other Men's Beasts". History and Theory 52 (2013): 13-28.

Garrard, Greg. "Ferality Tales". The Oxford Handbook of Ecocriticism. Ed. Greg Garrard. Oxford: Oxford University Press, 2014. 241-259.

"Bestial Humans and Sexual Animals: Zoophilia in Law and Literature". Animalities. Literary and Cultural Studies Beyond the Human. Ed. Michael Lundblad. Edinburgh: Edinburgh University Press, 2018. 211-235.

Heaney, Seamus. 100 Poems. London: Faber and Faber, 2018.

Hearne, Vicky. Animal Happiness. New York: HarperCollins, 1994.

Herman, David. "Narratology Beyond the Human". Diegesis 3. 2 (2014): 131-143. Narratology Beyond the Human: Storytelling and Animal Life. Oxford: Oxford University Press, 2018.

Kean, Hilda. Animal Rights. Political and Social Change in Britain since 1800. London: Reaktion, 1998.

. "Challenges for Historians Writing Animal-Human History: What Is Really Enough?”. Anthropozoös 25 (2012): s57-s72.

Lévinas, Emmanuel. "The Name of the Dog, or Natural Rights". Animal Philosophy - Ethics and Identity. Ed. Matthew Calarco and Peter Atterton. London: Continuum, 2004. 4750.

Low, Philip et al. "Cambridge Declaration on Consciousness". 2012. September 2020. http://fcmconference.org/img/CambridgeDeclarationOnConsciousness.pdf

Lundblad, Michael. The Birth of a Jungle. Animality in Progressive-Era U.S. Literature and Culture. Oxford: Oxford University Press, 2013.

Massumi, Brian. "The Thinking-Feeling of What Happens". Inflexions 1. 1 (May 2008): 1-40. July 2019. www.senselab.ca/inflexions/n1_massumihtml.html

McHugh, Susan. Animal Stories. Narrating Across Species Lines. Minneapolis: University of Minnesota Press, 2011.

Middelhoff, Frederike and Sebastian Schönbeck. "Coming to Terms: The Poetics of Morethan-Human Worlds". Texts, Animals, Environments. Zoopoetics and Ecopoetics. Ed. Frederike Middelhoff, Sebastian Schönbeck, Roland Borgards and Catrin Gersdorf. Freiburg i.B.: Rombach, 2019. 11-38.

Moe, Aaron. "Toward Zoopoetics. Rethinking Whitman's Original Energy". Walt Whitman Quarterly Review 31.3 (2013): 1-17.

Oliver, Kelly. Animal Lessons. How They Teach Us to Be Human. New York: Columbia University Press, 2009.

Paglia, Camille. Sexual Personae. Art and Decadence from Nefertiti to Emily Dickinson. New Haven, CT: Yale University Press, 1990.

Real, Hermann Josef. "Swift Horsing Around: or, The Madness of Reason". “... that I wished myself a horse" - The Horse as Representative of Cultural Change in Systems of Thought. Ed. Sonja Fielitz. Heidelberg: Universitatsverlag Winter, 2015. 61-81. 
Rigby, Kate. "Earth, World, Text: On the (Im)Possibility of Ecopoiesis". New Literary History 35. 3, (2004): 427-442.

. "Piping in their honey dreams': Towards a Creaturely Ecopoetics". Texts, Animals, Environments. Zoopoetics and Ecopoetics. Ed. Friederike Middelhoff, Sebastian Schönbeck, Roland Borgards and Catrin Gersdorf. Freiburg: Rombach, 2019. 281-293.

Rilke, Rainer Maria. The Notebooks of Malte Laurids Brigge. September 2020. https://archive.org/details/TheNotebooksOfMalteLauridsBrigge. . "The Dog". The New Poems: The Other Part. Woodbridge: Boydell \& Bewer, 2015. 375-376.

Rohman, Carrie. Stalking the Subject, Modernism and the Animal. New York: Columbia University Press, 2009.

Sax, Boria. Imaginary Animals. The Monstrous, the Wondrous and the Human. London: Reaktion.

Sedgwick, Eve Kosofsky. Touching Feeling: Affect, Pedagogy, Performativity. Durham: Duke University Press, 2003.

Swift, Gulliver. Gulliver's Travels [1726]. New York: Simon and Schuster/Pocket Books, 2005.

Tyler, Tom. Ciferae. A Bestiary in Five Fingers. Minneapolis: University of Minnesota Press, 2012.

Welling, Bart H. and Scottie Kapel. "The Return of the Animal: Presenting and Representing Non-Human Beings in the (Post-)Humanities Classroom”. Teaching Ecocriticism and Green Cultural Studies. Ed. Greg Garrard. Basingstoke: Palgrave Macmillan, 2012. 104-106.

Woodward, Wendy. The Animal Gaze: Animal Subjectivities in Southern African Narratives. Johannesburg: Wits University Press, 2008.

Yeats, W.B. The Collected Poems of W.B. Yeats. Ware: Wordsworth Poetry Library, 2008.

Received: 26 August 2019 Revised version accepted: 30 July 2020

Roman Bartosch is Associate Professor of Anglophone Literatures and Cultures at the University of Cologne, Germany. He is author and editor of more than ten books and over fifty scholarly articles and is interested in the environmental humanities, transcultural and ecocritical pedagogies, and the intersections of literature, pedagogy and literary theory. Recent publications include Literature, Pedagogy and Climate Change: Text Models for a Transcultural Ecology (Palgrave Macmillan, 2019) and, as editor, Cultivating Sustainability in Language and Literature Pedagogy: Steps to an Educational Ecology (Routledge, 2021).

roman.bartosch@uni-koeln.de 